\title{
3-メチルヒスチジン法は有効か
}

一一骨格筋タンパク犋分解速度測定法についての論争

\author{
門 脇 基 二, 野 口 忠 \\ (東京大学農学部農芸化学科)
}

学問の世界には常に論争があり, それが研究の進歩に 大きく貢献することは科学の歴史が証明している、筆者 らが従事している研究分野は，比較的地昧な分野であ るが，われわれが関心を持っているテーマの一つに，食 飢条件によって骨格肸タンバク筫の合成速度や分解速度 はとら調節されているか，とい5ものがある。畜産学の

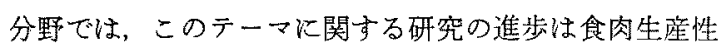
の向上と関係する大問題である.

さて，このテーマ追求の中心となる方法である骨格筋 タンパク質の合成・分解速度の測定法に関して, 今, 基 礎医学の研究者を含めて，世界で $N^{-}$ーメチルヒスチジン 法 (3-^チルヒスチジン法, 以下 3-MH 法と略) は有効 か，といら論争が茄る(1,2)。この諭争は，わ和れの健康 維持の立場からも大いに関心のあることなので，まずて れを知っていただくなた，1982年に Nature に揭載 された Millward らの論文(3)の要点代触れようと思う。 Millward（彼がファーストオーサーでない論文事多い が，彼らのグループの代表として以下彼の名前を使う） らは，彼ら自身が開発して良いち法であると主張してい る同位元灀標識アミノ酸の定速注入法によって, デュシ ェンヌ型の筋シストロフィ一患者 5 名の骨格筋タンパク 質の合成速度を測定した。そその結果，彼らの方法では， これらの患者の骨格筋タンパク質の合成速度が正常者の 䄪 $1 / 3$ (単位タンハク質量当り) k低下していることが 明らかになった。しかし，骨格筋タンパク質の量は毎日

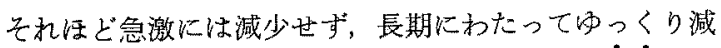
少していくのて, 铍らは, 骨格筋タンパク質の分解速度 も低下していると推定し, 論文を次のように結んでい る.「(3-MH 法を用いた研究結果によって)患者のタン ハク質分解速度が六進しているとの䛊った考えに基つい て, シストロフィー患者の筋肉タンパク質の分解を抑制 しよらと武みることは汇とえど価値がない，問題はタン パク質合成速度が顥著に低下していることである。すな わち, 可能ならば，筋肉タンパク質の合成速度を上界さ せるよらな治療手段をとることが合理的である.」
さて，いずれの組織のタンパク質についても言えるこ とであるが，合成量が分解量を上回れば，その組織の夕 ンパク質量は增加するし，逆ならば減少する。このこと は，正常組織であるらと，癌組織であるらと，シスト口 フィ一症状を示している筋肉であるちと同じである。 たがって，叭多質合成量か分解量か儿变動があ。 て，それがわれわれにとって不都合な变化であれば，合 成に欠陮があるのか分解に欠陷があるのかるつきとめ， その対策を考光るのは当然で，Millward bが筋ジスト ロフィーの治療に合成の低下忞防ぐ対策を考支るのが第 一であると結論したのも，彼らの結果が正しければ当然 のことであちら．しかし，本当に Millward の言らよう に、デュシェンス型のジストロフィ一患者では合成速度 が低下していると結論してよいのであるらかそこで， 本小論では，彼らが不適当な方法であると批判した 3MH 法の有效性と, 彼らが有效な方法と考党ている定 速注入法の問題点を比較考察しようと思う。

\section{3-MH 法}

1967 年, Asatoor と Armstrong ${ }^{(4)}$ および Johnson $5^{(5)}$ は，筋肉中のアクチン・ミオシンに 3-MH が存在 することを示し，こ机が尿中の 3-MH の起源であるら と推定した，その後，MIT の Young, Munro $b^{(6)}$ は, この特殊なアミノ酸の尿への排泄量を湘定することによ り，in vivo 飞㧍ける骨格筇タンパク質の分解速度を特 異的かつ簡便に測定できると報告した。かが国です，舲 引，西澤らは早くからこの方法に注目し，その有效性や 間題点，また応用について子活発に研究を展開しだ．

この 3- $\mathrm{MH}$ 法が提案される以前は, in vivoでの夕ン パク質のターンオーバー速度の測定法としては，ハルス 標識法や定速注入法といった標識アミノ酸を用いる力法 が開発，工夫されていた。しかし，生体内でのアミ，酸 の再利用の問題や，細胞内でのコンパートメントプール の問題など，末解決の問題が数多く残されていた。 そう したなかで，3-MH 法は，再利用のない，筋肉タンパタ 
質についている天然の目印（tag）上いう意味で, 従来の 方法の久点を補う，まさに絶妙の力法として登場したの である。

以来, このアミ，酸の体内分布，代謝，定量法等に関 寸る基整的知見や，タンパ質分解速度の指標となるべ き理諭的根拠について研究が大い优進展した。なお ち，骨格筋のミオフィブリル構成タンパク質であるフク チン 1 分子当り 1 分子, ミオシン 1 サブュニット当り 1 分子 (白筋の死) 存すること, これらの分子中の特定 のヒスチジン残基のメチル化は，タンバク質のベブチド 鎖形成捘に起ること,これらのタンパク質の分解に際し て，遊離した 3-MH は，メチル基がはずれることなく， また，タンパク質合成に再利用されることなく（対応す 万 3-MH-tRNA が存在しない）云のままの形で筋肉か ら放出されること, そして, 他の臟器でも利用, 蓄積 (ブタでは 3-メチルヒスチジルー $\beta$ アランン，すなわち バレニンの形での筋肉内の膟留があるとされている), 代謝（アセチル化は知られている）されることなく，速 やかに尿中へ排泄されること、などが確認さ机てい。 た、こ机らの事実は，ことごとくこのアミノ酸の in vivoでの分解速度測定の指標としての条件を满たする のであった，1970 年代後半には，こうした事実に基つ

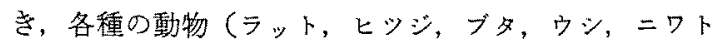
リ）で 3-MH 法が適用可能かどらかが検討され，また 臨床の場でも数多くの応用例が報告され始めた.

方法の確立に当って残された課題は，尿中に排泄さ れた 3-MH のらち，骨格筋以外の組織の寄与がどの程 度あるのか，3-MH 法と他の分解速度測定法の結果が一 致するか，などであった. Millward ら ${ }^{(8)}$ は，これらの課 題のらち，まず最初の問題に関して，計算ミスを犯しな がらも，骨格筋由来の 3-MH の量快予想上りはるか心 少ないのだといら，いわば 3-MH 法無効説を主張し始 めた，彼らの議論は，時として単純な計算ミスを犯した り，データの取报いに首尾一貫性を欠く点などがあり， 疑問を抱か梳る面も方るか，一方で，この方法の是非に ついて問題を提起し，その限界の認識を深めさせてきた といら意味では，貴重な存在である。それでは，まず彼 らの主張の根趑と乞の問題点を娭討してみ上う。

\section{II. 尿への 3-MH 排泄量に非骨格筋組織が どの程度寄与するか}

尿への 3-MH 排泄量か゚真飞骨格筋タンパク質分解速 度の指慓となりらるためには，排泄量の汪とんどすべて が骨格筋に由来することが必要である．動物体内におけ る 3-MH の存在に関しては, 西潀らによって, ラット
体内の各臓器における分布が詳細に調へらられた ${ }^{(0)}$ 。体内 総 3-MH に占める臟器の割合は，骨格能が王倒的に多 く $(90 \%)$ ，次いで皮盧 $(8.5 \%)$ ，消化管 $(1 \%)$ に認めら れた．しかし，尿中に排沚されてくる 3-MH は，その存 在量のみに比例して排泄されるのではなく，存在量とそ のターンオーバー速度との積に比例して排泄される。し たがって，むし，消化管や皮膚のタンパク質のターンオ 一バ一速度が，骨格筋上り極端に速ければ，それらの寄 与は無視できなくなってくる.3-MH の存在量に関して は，その值に疑問の余地は少ないが，ターンオーバー速 度については，まだ絶対的な方法がないため，測定によ

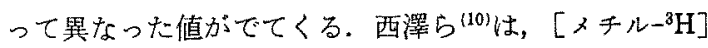
ィチオニンの 1 回投与で, 各組織での 3-MH の比放射 能の变化を測定し, 皮屇, 消化管のターンオーバー速度 をそれぞれ，5.0\%/日，7.3\%/日 とし，兩組織の尿中 3-MH 総排泄量に対する寄与を，最低 $16.6 \%$ と評価 し，残る $84.4 \%$ が骨格筋由来の最大量であるとした。

これに対して Millward ら ${ }^{(8)}$ は，彼らの定速注入法に よって，消化管，皮虚，骨格筋のターンオーバー速度を それぞれ，9.57，2.61，1.08\%/日とし，その尿中排泄量 に対する寄与は，9.8，6.8，24.9\% であり，三者を合計 しても $41.5 \%$ にしかならず, 残りは未知の組織由来で あるとして，尿への 3-MH 排琎量蛙格筋からの排浛 量を反映しないとした。しかしながらこの議論はすず Harris(11)により批判された．彼は，Millward らの主張 する数值に対して，単純な，乙かし重大な計算ミスのあ ることを指摘した，次いで，各荿器の奇与率の評価に は，量的に最も大きい骨格筋のターンオーバー速度の評 価が重要であり，その数値によって骨格筋の寄与率が 25\%から $110 \%$ にまで極端に変動してしまうこと，て して，Millward らの示した $1.08 \%$ といら值は，他の多 くの研究者の値と比べてみて，過少評価しているとし た。

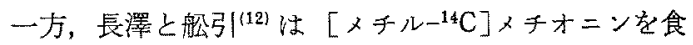
餌にまぜて每日楞取させる一種の継続投与法により，消 化管，皮膚，骨格筋のターンオーバ一速度をそれぞれ， 5.99, 8.72,2.87\%/日とし，尿中 3-MH に対する骨格筋 の寄与を $75.6 \%$ とした. また，ヒトでの特殊な例とし て，体内の骨格筋がほぼ完全に萎縮，消失してしまった 麻疩性患者に批る尿中 3-MH 排泄量を測定するとい ら実験るAfting らにより行われ，ヒトにおいてる非骨 格筋組織の寄与率は約 $28 \%$ とされた ${ }^{(13)}$.一方，Wassner と Li ${ }^{(14)}$ はこれらの議論に対し，後肢筋と腸管をを れぞれ別個に灌流するといら系を用いて，それぞれの等 与率を $59.41 \%$ と評価した。しかしこの結果は，上に 
述べてきたin vivoでの議論とは質的に異なる系でもあ り, 灌流手技に伴ら藏器の代謝変動が予想されることか ら，筆者らはその数值に関しては，in vivo の結果とは 同列化評価すべきではないと考えている.

以上の経緯で，現在のところ，尿中 3-MH 排泄量に 対する筋肉の奇与は，大方は䄪 $75 \%$ といらことに落ち ついているよらである。この奇与率ならば，常識的にみ て尿中 3-MH 排泄量が能肉タンパ質の分解速度を反 映するとみなしてよさそうに思える。けれどる，こ机は あくまで一つの生理的条件下での代表的な数值であり， 生理的条件がささざまに変動する場合にも，すべて同じ 寄与率で尿中に排泄されてくるといら保証はなく，今後 さらに追求すべき課題ではある。

\section{III. ミオフィブリルタンバク質のターンオーバー速} 度は骨格筋タンパク孟全体の速度を反映するか

3-MH 法は，疑密には 3-MH の代謝回転速度という ことなので, それからミオフィブリルタンパク質の分解 速度を推定し, さらに骨格筋タンパク質全体の分解速度 を推定するためには，アクチンとミオシンのターンオー パ一速度が同じかどらか，军たここれらとミオフィブリ ルやザルコプラズムなどに存在する他のタンパク質のタ ーンオーバー速度との関㐿はどらかということが問題に なる。

Lobley と Lovie ${ }^{(15)}$ は, 標識アミノ酸投与後の総骨格 筋タンパク質, ミオフィプリル，フクトミオシン、ザル ユプラズム各タンパク質の比放射能を調べ，すべて同じ 比放射能であったことから，各タンパク質のターンオー バー速度には大きな差はないと結論している。 また，長 澤と船引(12)は，アクチンとミオンンの比放射能を測定し， それぞれの值は：ミオンンのはらがアクチンより約 4 倍高いが，両者の加重平均值は骨格筋タンパク質全体の 值とよく一致することから，3-MH のターンオーバ一速 度は，骨格筋タンパク質全体のターンオーパ一速度をよ く代表すると結論している，これらを含め，多くの報告 を総合すると，現在のところ，骨格筋タンパク質全体の 分解速度は，ミオフィプリルタンパ質に比べやや高い 傾向にあること，また，ミオシンのターンオーバ一速度 はアクチンと同じかや速いと考兄てよからう。すなわ ら，骨格筋中の個々のタンパ質は個有のターンオーバ 一速度で代謝されているが，全体の平均值としてみた場 合は，現在のところ，フクチン・ミオシンの平均值と骨 格筋タンパク質全体のターンオーバー速度には大きな差 はなく、3-MH 法が骨格筋タンバク質全体の分解速度測 定法として，そら間違った数值を出すことはないとい党
そらである。しかし，この見解には反論が㚣ることも事 実である(16)

\section{3-MH 法の結果は他の測定法の結果と 一致するか}

永中 3-MH 排泄量がどの程度骨格筋に由来するかと いう問題はもちろん重要であるが，この方法の有效性を 確立するためには，この方法に上って得られる結果が， 他の骨格筇タンパク質の分解速度测定法の結果とどの程 度対比しらるかが問題となる。この問題に言及するため に，まず従来の in vivo に括汀る測定法について少し触 れて㧍きたい。

古くは，in vivo に括斿るタンパ質のターンオーパ 一速度の测定法は，定常状態に苏る動物に標識了ミ/酸 を 1 回投与し，それを取り込んだタンパク質の比放射能 の減衰を経時的に追跡して半減期 $\left(t_{1 / 2}\right) な り$, 分解速度 定数 $(K \mathrm{~d})$ を求めていた。 しかし，この方法では，アミ ノ酸の再利用の影響が大きく，どらしても分解速度が過 小評価される欠点があった，また，逆に，投与後短時間 での取込み速度から合成速度を計算しょうとすると，前 駆体の比放射能が経時的に大きく変動するため，その評 洒は非常に困難で，誤差を伴いやすかった，そこで, Millward らは，定速注入法という方法を工夫・提案し た(17)。これは，標識アミノ酸を一定時間連続的に動物に 注入し, 前駆体の比放射能々, 生成物への標識了ミノ酸 の取込及速度を测定し，設定したモデルに基ついて， タンパク質の合成速度を算出する方法である。この方法 は，モデルが正しければ，標識アミノ酸を定速で注入し た後， 1 回だけ前駆体の比放射能と生成物への標識アミ ノ酸の取込み量を測定すればよいまた，別法として は，大と光“疑似平衡”であっても，前駆体の比放射能が プラトーに達するまで標識つミノ酸を与克，去の後の 2 点で生成物（タンパク質）へ取り込をれた標識つミノ酸 量を測定することにより，タンパク質合成速度を算出す る方法が尔る。

彼らは，このち法を胃いて骨格筋タンバク質の合成速 度を測定し，また体タンパク質量の变化から骨格筋タン 汸質量の变化を求め，穴の差から分解速度を計算して 3-MH 法による值と比較したところ，ラットを絶食にす ると，杘への 3-MH 排泄量は，絶食後速やかに增加し ていくが，定速注入法によって算出した分解速度は，絶 食初期にあっては增加せず，両方法で異なる結果となる ことを報告した(18)．彼らは，この矛盾した結果の解釈と して，增加した 3-MH は，主に腸管由来ではないかと推 定している(199. 在た，冒頭に紹介した筋ジストロフィー 
腎者の場合の結論もこの定速注入法が正しいことが前 提となっている. 彼らの定速注入法は，現在 in vivoで のタンパク筫のターンオーバー速度測定法として, 主に 彼ら自身によって広䉐に使用されているが，実際には， かなり多くの問題点を含んでいると考兄られる。专の最 大のものは，タンパク質合成の直接の前駆体プールを何 と仮定するかという点汇る。この前駆体プールの問題 自体が，現在のタンパ質合成速度論上の大問題であ り，肝臓や筋肉，その他の組織て，血獎遊墔 か，細胞内遊離アミノ酸か，またはその両方か，はたを た，それがアミノ酸の種類によって異なるのか，動物の 生理的状態によって異なるのか，等々多くの問題が指摘 されている(17). そして，この前駆体プールを何に設定す るかによって，合成速度の值は非常に大きく異なってく る、たとえば，血獎アルブミンの合成速度をこの方法で 測定すると，肝淢の遊離つミノ酸を前駆体とした場合に は“異常に速い’合成速度を得てしまう。

こらした状況から，最近 Millward らのグループの Garlick ら ${ }^{(20,21)}$ は，前駆体プールの問題を無視できるつ ミノ酸の大量投与法を提案している。この方法は，一定 の比放射能のアミノ酸を動物に 1 回与古る点は旧来の方 法と同じだが，その投与量を多くすることにより，前駆 体と仮定した組織内の遊離アミ，酸プールの比放射能を 短時間に血墏遊離アミノ酸の比放射能に近づけ上うとす る方法である。この方法は，特定のアミ八酸の大量投与 がもたらす動物の生理的条件の变動の問題があり，また 方法自体の有效性の検討が十分行われていない，したが って，現在のところ，多くの議論は，いまだ定速注入法に よる結果化基ついて行われている．Millward らは，こ の方法を用いてラットについて多数の論文を書いている が，その多くで，每日骨格筋で新たに合成されているタ ソペク質量は，骨格筋の全タンパク質量の 10〜15\% て あるとしている、䐅いほうの数值を記した論文でも，ほ とんどが $5 \%$ 以上である. Garlick らの大量投与法で も，骨格筋の部位によって若干異なるが, 17〜21\%とさ れている、しかし，Millward らが 3-MH 法を批判する 場合には，こ机らの数值を使用甘ず，常に 1 2\% との 数值を用いるのす理解に苦しむ. 3-MH 法では，通常 2〜3\% との值が得られるのである. 最近彼らは，さら に詳細な議諭をしているが(16)，それらに関しては別の機 会に論じることにしたい。な拉，船引ら ${ }^{(22)}$ は，同じラッ トについて，パルス投与法と 3-MH 法の二法を同時に 適用することを試み，両方法で得られる結果がおお叔むね 一致すると報告している。

さて，臨床的には，骨格筋タンパ質の分解速度が何
\%かが正確に測れなくても，分解速度の変化の方向（速 くなったか，逯くなったか）の指標として 3-MH の尿 への排泄量の変動が使兑れぱ，そ机はそれとして洒值の あることであろう。

系は異なるが，筆者らは，ラット後肢筋灌流系を用い て，灌流液中に放出される 3-MH を測定し，絶食炕伴 い, 3-MH はチロシン, フェニルアラニンの放出と同様 に経時的に增加すること学観察した (28)。これは，尿への 排泄量の增加とよく一致している。 また，ジストロフ、 一動物の骨格筋を整流すると，3-MH の放出は対照の動 物上り多いことも Li らに上り八ムスターで確認されて 拉り，これもやはり尿への排泪傾向と一致している( ${ }^{(24)}$. このよらに，現在のところ，筋肉からの放出と尿への排 泄が矛盾する結果は見当たらないが，この種の議論は一 つでも反証が出れば意味を失らので，ざざまな系で今 後も研究を続けるべきであると考克ている.

な拉，尿への 3-MH 排泄量から分解速度を推定する ことに真向から反対している Millward らは, 最近血中 3-MH の骨格筋での動静脈差によって分解速度の変動 方向を推定する方法を提案している(2).たしかに，理諭 的には尿への排泄量から推定するよりる，より直接的な 方法には違いない、筆者らもこの方法に検討を加党た が，動脈血中の $3-\mathrm{MH}$ 濃度 (3 4 $\mathrm{nmol} / \mathrm{ml}$ plasma) が，血液が動脈から骨格筋を経て静脈一出現するまでの 短時間に血中へ放出されるごくわずかな 3-MH 量に比 して高いため，動静脈濃度差を再現性よく測定するの は，かなり困難であるとの判断に至った．また，臨床的 に用いる場合には，簡便性とそこから得られる情報の質 とを比較して，やはり現段階では，尿への 3-MH の排 泄量の測定のはらが有用であるう。

なお，3-MH の排泄量は，1 日程度の期間の尿全体を 集めて分析した活らが得られる情報の価值も大きく精度 も高いと筆者らは考觉ている.臨床的には 1 日尿をとる ことの不便さのため，3-MH/クレアチニン比を求める 場合が多いようである，この場合は，筋肉量の指標とさ れるクレアチニンの排泄量が，とくに急激な筋肉量の変 動がある場合には変動してしまい，必す゚しも筋肉量の指 標とならない可能性が饬ることに注意する必要がある。

\section{V. in situ 系への 3-MH 法の適用}

以上ではあくまです in vivoに拈ける筋肉タンパク質 分解速度の指標としての 3-MH 法について議諭を進め てきた。 そこで最後にin situの系に打ける 3-MH 法の 適用について若干述べてみたい。

3-MH は, 当初上り，尿中には容易飞検出されるが， 
組織中や血中では存在量が徽量で検出が困難だったた め, 専ら in vivoでの議論に精力が注がれてきた、けれ ども，最近の高速液体クロマトグラフィーの進步と，特 異的かつ簢便な蛍光分析法の開発により，pmol レベル の微量分析が可能となり ${ }^{(25)}$, in situ 系への3-MH 法の 適用が可能となった。筆者らは in situ の系として，後 肢筋灌流法を用いているが，この系の特徵としては，ま ず, in vivoで大きな議論になった消化管の奇与を全く 整視することができることである，皮䖉の寄与も卧とん ど考慮の必要がないとされている(14)。立た，徒来から in situ p in vitro の系での分解速度の指標であったチ ロシンやフェニルアラニンの放出量は，これらのアミ， 酸がタンパク質合成へ再利用される問題があるために, 常にタンパク質合成阻害剂シクロへキシミドの存在下で の湘定が必要であり，この阻害剤のタンパク質分解に対 する影響が䜿念されてきた，3-MH の場合には，この点 も考慮する必要が全くないといら利点があるほか，チロ シン, フェニルアラニンは，笳肉タンパク質全体の分解 速度の平均値を示すのに知し，上述のよ5に3-MH は ミオフィブリルタンパク質，とくにアクチン：ミオシン のみを反映するといら特徵がある。

この系を用いて，筆者らは，絶食 ${ }^{(23)}$, 梧尿病 ${ }^{(26)}, 1 ン$

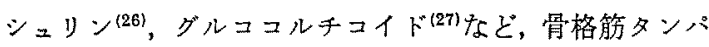
ク留のターンオーバーに影響を与古る因子について，そ の影響を定量的に実証してきた.今後も：ミオフィブリ ルタンパ質の分解速度論，調節諭の発展のためにこ の方法は有効な手段として用いられていくことと考えら れる。

\section{おわりに}

私たらは現在 Millward らの in vivoでの定速注入法 が有効か無効かを結論するデータを持っていない，既述 のよ5に，有効な方法か十分開発されていない現在，不 適当と結論することも不可能である。しかし，われわれ の実験結果，影よびわれわれが集めえた現在の知見から は，3-MH 法にしても，定速注入法にしても，有効であ るとか無效であるとか結論するのは，どら考えても早阡 であると言わざるをえない，それを存知であるて筆者ら の私見というより感想を述べれば，定速注入法よりは 3-MH 法の活らが問題が少ないのではないか，また，尿 をとれば則定できる非侵襲法であるといら最大の特質も 考觉あせると，少なくとも臨床的には，Ballard の主 張するように(1)，限界を承知して使いさえすれば，3-MH 法のほらが簡便で使いやすいのではないか，といらとこ ろであるら。しかし，3-MH 法が有效か無效が決定寸
るのは，標識つミノ酸を用いたより正確なタンパク質合 成速度もしくは分解速度測定法の開発にあることを忘れ てはならないと考党る。

初めに述べたように，骨格筇のタンパク質合成速度や 分解速度を知万ことは，畜肉生産のうえでも大变価值の 大きいことである：簡便な 3-MH 法が医学や策学学の 分野ばかりでなく畜産学の分野でもより広く使われる日 は近いと予想される。

この小論で，骨格筋タンバク質の合成速度，分解速度 の测定といら特殊な一つの問題が，農学中医学の分野に このような波紋を引き起こしていることを諳者の皆様が 御理解くださり，この分野の研究の発展汇関心を持って いただければありがたいと思っている。

本稿の起稿をすすめてくださり，有益な御助言，御高 閲をいただいた東京大学教授内藤博先生に厚く御礼申 し上げます。また，贵重な御意見をお聞かせくださった 東京農工大学教授船引龍平先生に厚く御礼申し上げを す.

(1) F. J. Ballard and F.M. Tomas: Clin. Sci., 65, 209 (1983).

(2) M. J. Rennie and D. J. Millward: Clin. Sci., 65, 217 (1983).

(3) M. J. Rennie, R. H. T. Edwards, D. J. Millward, S. L. Wolman, D. Halliday and D. E. Matthews : Nature, 296, 165 (1982).

(4) A.M. Asatoor and M. D. Armstrong:Biochem. Biophys, Res. Commun., 26, 168 (1967).

(5) P. Johnson, C.I. Harris and S. V. Perry : Biochem. J., 105, 361 (1967).

(6) V.R. Young and H. N. Munro: Fed. Proc., 37, 2291 (1978).

（7）西濢直行：栄食誌，36，409（1983）.

(8) D. J. Millward, P.C. Bates, G. K. Grimble, J. G. Brown, M. Nathan and M. J. Rennie: Biochem. J, 190, 225 (1980).

(9) N. Nishizawa, M. Shimbo, S. Hareyama and R. Funabiki : Br. J. Nutr., 37, 345 (1977).

(10) N. Nishizawa, T. Noguchi, S. Hareyama and R. Funabiki : Br. J. Nutr., 38, 149 (1977).

(11) C. I. Harris : Biochem. J., 194, 1011 (1981).

(12) T. Nagasawa and R. Funabiki : J. Biochem., 89, 1155 (1981).

(13) E. G. Afting, W. Bernhardt, R. W. C. Janzen and H. J. Röthig : Biochem. J., 200, 449 (1981)

(14) S. J. Wassner and J. B. Li : Am. J. Physiol., I 243, E 293 (1982). 
(15) G. E. Lobley and J. M. Lovie: Biochem. J., 182, 867 (1979).

(16) P.C. Bates, G. K. Grimble, M.P. Sparrow and D. J. Millward : Biochem. J., 214, 593 (1983).

(17) J.C. Waterlow, P. J. Garlick and D. J. Millward: "Protein Turnover in Mammalian Tissues and in the Whole Body," NorthHolland, Amsterdam, 1978.

(18) L. Cotellesa, P.W. Emery and M. J. Rennie: Proc. Nutr. Soc,, 42, 26 A (1983).

(19) P.W.Emery, L. Cotellesa, M. Holness and M. J. Rennie : Proc. Nutr. Soc., 42, 136 A (1983).

(20) M. A. McNurlan, A. M. Tomkins and P. J. Garlick : Biochem. J., 178, 373 (1979).
(21) P. J. Garlick, M. A. McNurlan and V. R. Preedy : Biochem. J., 192, 719 (1980).

（22）池永和之, 舩引龍平：日本典亖化学会昭和57年 度大会講演要旨集，1982， p. 301.

(23) M. Kadowaki, T. Hirata, T. Noguchi and H. Naito : in preparation.

(24) J. B. Li : Am. J. Physiol., 239, E 401 (1980).

(25) S. J. Wassner, J. L. Schlitzer and J. B. Li : Anal. Biochem., 104, 284 (1980).

(26) T. Nagasawa, M. Kadowaki, T. Noguchi and H. Naito : Agric. Biol. Chem., 46, 3023 (1982).

(27) M. Kadowaki, F. Niwa, T. Nagasawa, T. Noguchi and H. Naito : in preparation. 